\title{
Review \\ The inextricable link between atherosclerosis and prototypical inflammatory diseases rheumatoid arthritis and systemic lupus erythematosus
}

\author{
Louise E Full, Cristina Ruisanchez and Claudia Monaco
}

Kennedy Institute of Rheumatology Division, Faculty of Medicine, Imperial College, Aspenlea Road, London, W6 8LH, UK

Corresponding author: Claudia Monaco, c.monaco@imperial.ac.uk

Published: 3 April 2009

This article is online at http://arthritis-research.com/content/11/2/217

(c) 2009 BioMed Central Ltd

Arthritis Research \& Therapy 2009, 11:217 (doi:10.1186/ar2631)

\section{The clinical impact of atherosclerosis in inflammatory diseases} Atherosclerosis and rheumatoid arthritis

Cardiovascular manifestations such as pericarditis, myocarditis and atrioventricular block are classic complications of RA and SLE. However, most of the cardiovascular mortality in RA patients is not due to these manifestations but rather to ischaemic heart disease secondary to coronary atherosclerosis [3]. In the Nurses' Health Study [4], patients with RA had more than twofold greater risk for myocardial infarction (MI) compared with patients without RA. Worryingly, RA patients are almost six times more likely to have had an undiagnosed $\mathrm{Ml}$ and twice as likely to experience sudden death [5]. RA patients are also far less likely to report forewarning symptoms, such as angina $[5,6]$, potentially hampering early detection of atherosclerotic disease.

In support of these observations, RA patients have an increased prevalence of subclinical atherosclerosis, with a greater incidence of carotid artery plaque and increased carotid intima/media thickness (IMT) $[7,8]$ as well as multivessel coronary artery disease compared with control individuals [9].

\section{Systemic lupus erythematosus and cardiovascular disease}

Three decades ago, Urowitz and coworkers [10] recognized that CVD and MI were major causes of mortality in patients with SLE. In fact, patients with SLE are five or six times more likely to have a significant coronary event compared with the general population. Remarkably, women with SLE between the ages of 35 and 44 years have a 50 -fold increased risk for

$\mathrm{aCL}=$ anticardiolipin; $\mathrm{ACS}=$ acute coronary syndrome; apo = apolipoprotein; CVD = cardiovascular disease; GPI $=$ glycoprotein I; HDL $=$ highdensity lipoprotein; IFN = interferon; IL = interleukin; IMT = intima/media thickness; LDL = low-density lipoprotein; MHC = major histocompatibility complex; $\mathrm{Ml}=$ myocardial infarction; $\mathrm{MIF}=$ macrophage migration inhibitory factor; $\mathrm{MMP}=$ matrix metalloproteinase; NF- $\mathrm{KB}=\mathrm{nuclear}$ factor- $\mathrm{\kappa B}$; oxLDL = oxidized low-density lipoprotein; RA = rheumatoid arthritis; SLE = systemic lupus erythematosus; $S M C=$ smooth muscle cell; SNP $=$ single nucleotide polymorphism; TGF $=$ transforming growth factor; Th $=$ T-helper; TLR $=$ Toll-like receptor; TNF $=$ tumour necrosis factor. 
(a)

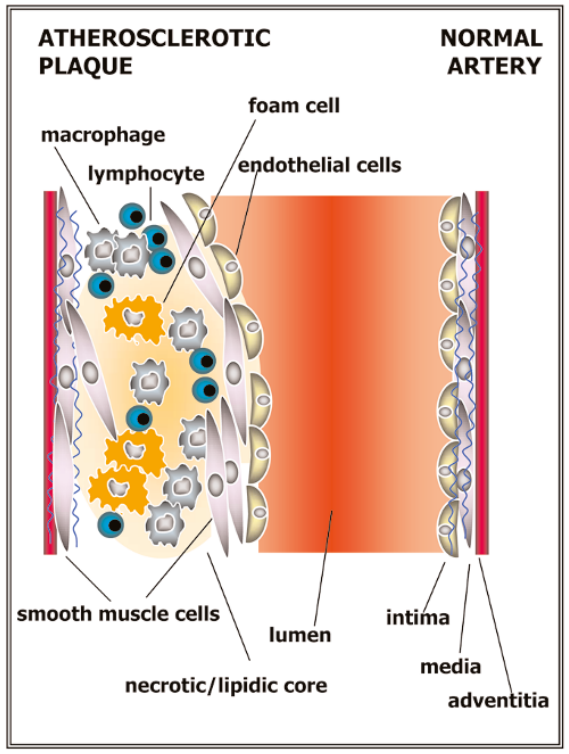

(b)

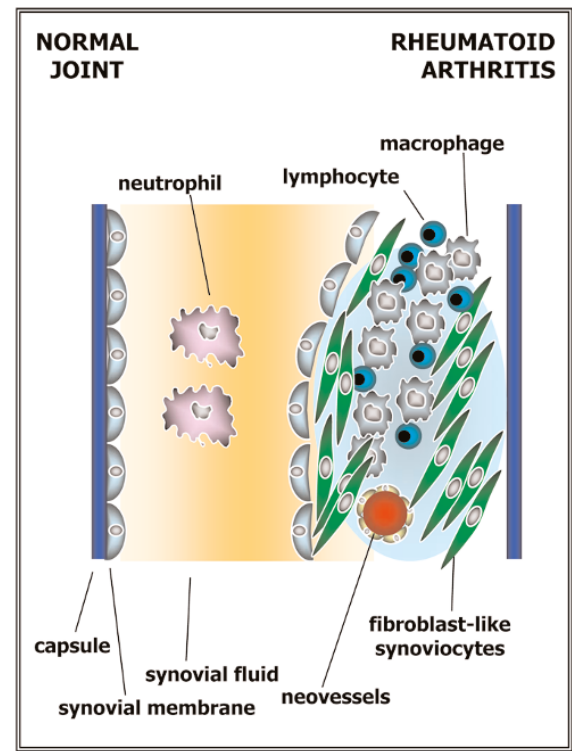

Similarities between the atherosclerotic plaque and rheumatoid arthritis joint. The (a) atherosclerotic plaque has many features in common with (b) rheumatoid arthritic synovium. First, in both diseases, blood-borne mononuclear cells are recruited to sites that are devoid of any significant inflammation in physiological conditions. Second, upregulation of cytokines and matrix-degrading enzymes is central to the pathogenesis of both diseases. Third, both in rheumatoid arthritis and atherosclerosis, immune cells do not target resident cells in the same way that diabetogenic T cells directly destroy pancreatic islets. Instead, immune cells begin complex interactions with the resident cell types, which proliferate, change their properties and phenotype, and contribute to the inflammatory process and tissue destruction.

Ml compared with age-matched and sex-matched control individuals [11]. In a Canadian cohort of SLE patients, the relative risk for $\mathrm{Ml}$ was 10.1 , that for death due to $\mathrm{CHD}$ was 17 , and that for stroke was 7.9 [12]. SLE patients have increased subclinical atherosclerosis compared with the general population, with a greater prevalence of carotid plaques and increased IMT [13,14]. Myocardial single photon emission computed tomography scanning has revealed coronary artery disease in $40 \%$ of patients with SLE $[15,16]$, although coronary artery calcification is more prevalent in lupus without underlying CVD [17].

\section{Risk factors for cardiovascular events in patients with rheumatoid arthritis and systemic lupus erythematosus}

\section{Clustering of traditional atherogenic risk factors}

RA and SLE patients have an overall increased frequency of traditional cardiovascular risk factors $[3,10,18,19]$. Smoking is associated with subclinical atherosclerosis in patients with RA [20]. Hypertension is also an important risk factor for CVD in RA and SLE $[21,22]$.

A particular type of dyslipidaemia is present in patients with RA. This is characterized by low high-density lipoprotein (HDL), raised triglycerides and low levels of low-density lipoprotein (LDL) [23]. Interestingly, such a lipid profile is detectable in those individuals who go on to develop RA at least 10 years before the onset of symptoms [24]. Dyslipo- proteinaemia in SLE is slightly different from that in RA, characterized by elevated levels of very-low-density lipoprotein cholesterol and triglycerides, high or unchanged LDL, low levels of HDL and disturbance in chylomicron metabolism. Hence, low HDL levels are a common trait in RA and SLE. Low HDL in the general population exhibits a strong inverse correlation with CVD events, even in the presence of low LDL or statin therapy. Changes in lipoprotein functions have also been described. For instance, LDL from RA patients has an increased capacity to bind proteoglycans, which is considered an important early step in atherogenesis [25]. High levels of the pro-atherogenic lipid particle lipoprotein-a have been detected in both diseases, as well as elevated levels of circulating oxidized LDL (oxLDL) [26]. Paraoxonase, an enzyme that binds to HDL and prevents oxidation of LDL, was shown to have reduced activity in patients with SLE and primary antiphospholipid syndrome [27].

Patients with RA and SLE have a higher prevalence of metabolic syndrome [28], which includes obesity, dyslipidaemia, hypertension and insulin resistance. Additionally, patients with RA and SLE are less physically active than individuals without the disease, which may also contribute to accelerated atherosclerosis.

\section{Traditional therapies and cardiovascular risk}

The effect of chronic use of drugs commonly employed to treat RA and SLE in promoting or suppressing atherogenesis 
is extensively reviewed elsewhere $[23,29]$. Such drugs can affect the progression of atherosclerosis either by acting on the inflammatory process or by altering cardiovascular risk factors. Corticosteroids, for instance, promote insulin resistance, weight gain, fluid retention and hypertension. Nonetheless, within the context of inflammatory diseases their net effect is likely to be complex because of their beneficial effects on the ongoing inflammation. In the COBRA (Combination Therapy in Early Rheumatoid Arthritis) study [30], high-dose steroids used in conjunction with other disease-modifying antirheumatic drugs improved the total cholesterol to HDL ratio, with a linear association with the Disease Activity Score. However, in a different study [31] glucocorticoid exposure was associated with carotid plaque and arterial incompressibility.

The effect of methotrexate is similarly complex. Methotrexate use causes elevation in serum homocysteine levels by folate depletion. This effect could promote atherogenesis as because hyperhomocysteinaemia is an independent risk factor associated with CVD in the general population as well as in patients with SLE [32]. However, in a prospective study involving 1,240 patients with RA [33], therapy with methotrexate was associated with improved survival by reducing CVD mortality by $70 \%$. Folate supplementation is a plausible approach to counteract hyperhomocysteinaemia [34] and is currently a matter of debate. It is worth noting that in a trial of 5,442 women conducted over 7 years [35], daily supplementation with a combination of folate and vitamins $B_{6}$ and $B_{12}$ was able to reduce hyperhomocysteinaemia, but it was unable to abolish CVD risk.

Nonsteroidal anti-inflammatory drugs are among the most commonly used anti-inflammatory interventions. This group of drugs has a much broader range of actions than simply inhibition of inflammation, including their effect on prostaglandin metabolism, in which atheroprotective mediators (for example, prostacyclin) are also inhibited. In a recent metaanalysis [36] selective cyclo-oxygenase- 2 inhibitors and highdose regimens of ibuprofen and diclofenac were found to be associated with a moderate increase in the risk for adverse cardiovascular events.

\section{Inflammatory burden and atherosclerosis}

Both SLE and RA patients exhibit an increased prevalence of pro-atherogenic risk factors, which may very well contribute to the burden of CVD events and atherosclerotic disease. However, there is growing evidence that this is only one side of the story.

In a number of studies, even after correction for classical risk factors for CVD, both RA and SLE remain independently associated with clinical and subclinical atherosclerosis $[9,18]$ (Tables 1 and 2). In a cohort of 296 SLE patients followed for a mean of 8.6 years, CVD events were substantially higher than would be predicted on the basis of traditional factors alone, using the Framingham risk stratification method [12]. In a study conducted in the Pima Indian population, the number of swollen joints was predictive of death from CVD [37]. Similarly, the presence of severe extra-articular disease clearly increased the risk for cardiovascular events in patients with RA [2,38]. Duration of the disease has also been associated with the presence of carotid plaques [39]. A recent study conducted in $631 \mathrm{RA}$ patients [40] showed that the rate at which IMT increased was proportional to the duration of disease. Another study [41], in 155 RA patients, also demonstrated that patients with longstanding disease have an increased Framingham risk score compared with patients with early disease. (The Framingham risk score is used to derive an estimated risk for developing coronary heart disease within 10 years and is based on age, sex, total and HDL cholesterol, blood pressure, diabetes and smoking.) High Framingham scores were associated with coronary artery calcification. The increased risk for CVD in RA patients was also shown to be present 2 years before the fulfilment of criteria for RA [7]. In addition, patients with very early inflammatory polyarthritis are at increased risk for premature death from CVD when their serum is positive for rheumatoid factor [42]. These findings suggest that even preclinical inflammation may contribute to increased risk for cardiovascular events.

\section{Disease initiation and endothelial activation}

In humans, atherosclerotic lesions occur in the large and medium sized arteries and are characterized by an asymmetrical focal thickening of the innermost layer of the arterial wall, the intima. Atherosclerosis is a multifactorial disease with strong epidemiological associations with a variety of lifestyle-related and genetics-related risk factors (for example, dyslipidaemia, smoking, diabetes mellitus and hypertension). The common pathway, through which all of these risk factors lead to atherosclerosis development, is endothelial activation and subsequent endothelial dysfunction. The sequence of events that leads to early stages of atherogenesis has been mostly characterized under conditions of hypercholesterolaemia. Excess LDLs enter the intima where they are retained by matrix proteoglycans. Here they are subject to oxidative and enzymatic modifications, leading to formation of pro-inflammatory phospholipids that may induce endothelial cell activation [43].

Pro-inflammatory mediators such as tumour necrosis factor (TNF)- $\alpha$, are strongly linked to endothelial activation and dysfunction [44]. Persistent endothelial activation leads to endothelial dysfunction, characterized by reduced production of nitric oxide and increased expression of adhesion molecules and chemokines [1], resulting in impaired vasorelaxation and recruitment of blood-borne mononuclear cells such as monocytes and $\mathrm{T}$ lymphocytes. Endothelial dysfunction has been detected in RA and SLE patients by noninvasive tests such as the brachial flow-mediated dilatation, as extensively reviewed elsewhere $[45,46]$. Endothelial 
Table 1

Studies evaluating the risk of coronary heart disease in rheumatoid arthritis

\begin{tabular}{|c|c|c|c|c|}
\hline $\begin{array}{l}\text { [Reference] } \\
\text { (year) }\end{array}$ & Study design & RA definition & $n$ & Estimated risk \\
\hline [18] (2001) & Prospective cohort & ACR 1987 criteria & 236 & $\begin{array}{l}\text { 3.86-fold of combined CV events } \\
\text { ( } \mathrm{Ml}+\text { revascularization }+ \text { stroke) }\end{array}$ \\
\hline [4] (2003) & Prospective cohort & ACR 1987 criteria & 525 & $\begin{array}{l}\text { 2-fold risk for } \mathrm{Ml} \\
\text { 1.48-fold risk for stroke } \\
\text { RA > } 10 \text { years: } 3 \text {-fold risk for } \mathrm{Ml}\end{array}$ \\
\hline [84] (2003) & Cross-sectional survey & Rheumatologist diagnosis & 9,093 & 2.15-fold risk for $\mathrm{Ml}$ \\
\hline [19] (2003) & Prospective cohort & Physician diagnosis & 11,633 & 1.6-fold risk for Ml \\
\hline [5] (2005) & Retrospective cohort & ACR 1987 criteria & 603 & $\begin{array}{l}\text { 2-fold risk for } \mathrm{Ml} \\
\text { 6-fold risk for unrecognized MI } \\
\text { 2-fold risk sudden death }\end{array}$ \\
\hline [85] (2007) & Retrospective cohort & ACR 1987 criteria & 239 & $\begin{array}{l}0.1 \% \text { to } 0.3 \% / \text { year } \mathrm{Ml} \\
0.07 \% / \text { year stroke }\end{array}$ \\
\hline [2] (2008) & Retrospective cohort & Rheumatologist diagnosis & 4,363 & $\begin{array}{l}3.2 \% \text { prevalence } \mathrm{MI} \\
1.9 \% \text { prevalence stroke }\end{array}$ \\
\hline
\end{tabular}

ACR, American College of Rheumatology; CHD, coronary heart disease; CVD, cardiovascular disease; MI, myocardial infarction; RA, rheumatoid arrthritis.

Table 2

Studies evaluating the risk of coronary heart disease in systemic lupus erythematosus

\begin{tabular}{|c|c|c|c|c|}
\hline $\begin{array}{l}\text { [Reference] } \\
\text { (year) }\end{array}$ & Study design & SLE definition & $n$ & Estimated risk \\
\hline [11] (1997) & Prospective cohort & ACR criteria for SLE & 498 & $\begin{array}{l}5 \text {-fold risk for } \mathrm{Ml} \\
50 \text {-fold risk in ages } 35 \text { to } 44 \text { years }\end{array}$ \\
\hline [86] (1999) & Retrospective cohort & Rheumatologist diagnosis & 8,742 & $\begin{array}{l}\text { 2.27-fold risk for } \mathrm{Ml} \\
\text { 3.8-fold risk for chronic heart failure }\end{array}$ \\
\hline [12] (2001) & Retrospective cohort & Rheumatologist diagnosis & 296 & $\begin{array}{l}\text { 17.0-fold risk for CVD } \\
\text { 10.1-fold risk for Ml } \\
\text { 7.9-fold risk for stroke }\end{array}$ \\
\hline [87] (2004) & $\begin{array}{l}\text { Cross-sectional, } \\
\text { prospective }\end{array}$ & ACR criteria for SLE & $\begin{array}{l}202 \text { (cross-sectional), } \\
47 \text { (prospective) }\end{array}$ & $\begin{array}{l}\text { 1.4-fold risk for CHD } \\
0.6 \text {-fold risk for stroke } \\
8.5 \% \text { CHD events } \\
10 \% \text { stroke follow up }\end{array}$ \\
\hline [88] (2004) & Case control & Physician diagnosis & 770 & 1.46 risk for $\mathrm{Ml}$ \\
\hline
\end{tabular}

ACR, American College of Rheumatology; CHD, coronary heart disease; CVD, cardiovascular disease; MI, myocardial infarction; SLE, systemic lupus erythematosus.

dysfunction might reflect CVD risk factor burden in these individuals, but it could also indicate systemic inflammation and prolonged exposure of endothelial cells to pro-inflammatory cytokines such as TNF- $\alpha$ (vide infra). Interestingly, in animal models as well as in human clinical trials in RA and SLE patients, high doses of statins can reduce inflammation and improve endothelial function [47]. Statins are effective in lowering LDL-cholesterol, but they also have immunomodulatory properties [48]. Both mechanisms of action might be at play in reducing endothelial dysfunction.

\section{Progression of atherosclerotic disease}

Although atherosclerosis is initiated by the exposure to traditional lifestyle risk factors, inflammation is a key driving force at each stage of atherosclerosis development [43], with both innate and adaptive cellular components of inflammation involved in disease progression (Figure 2).

Myeloid cells, cytokines and atherosclerosis progression Recruitment of blood-borne mononuclear cells is a key step in atherogenesis. Even in hypercholesterolaemic murine models 


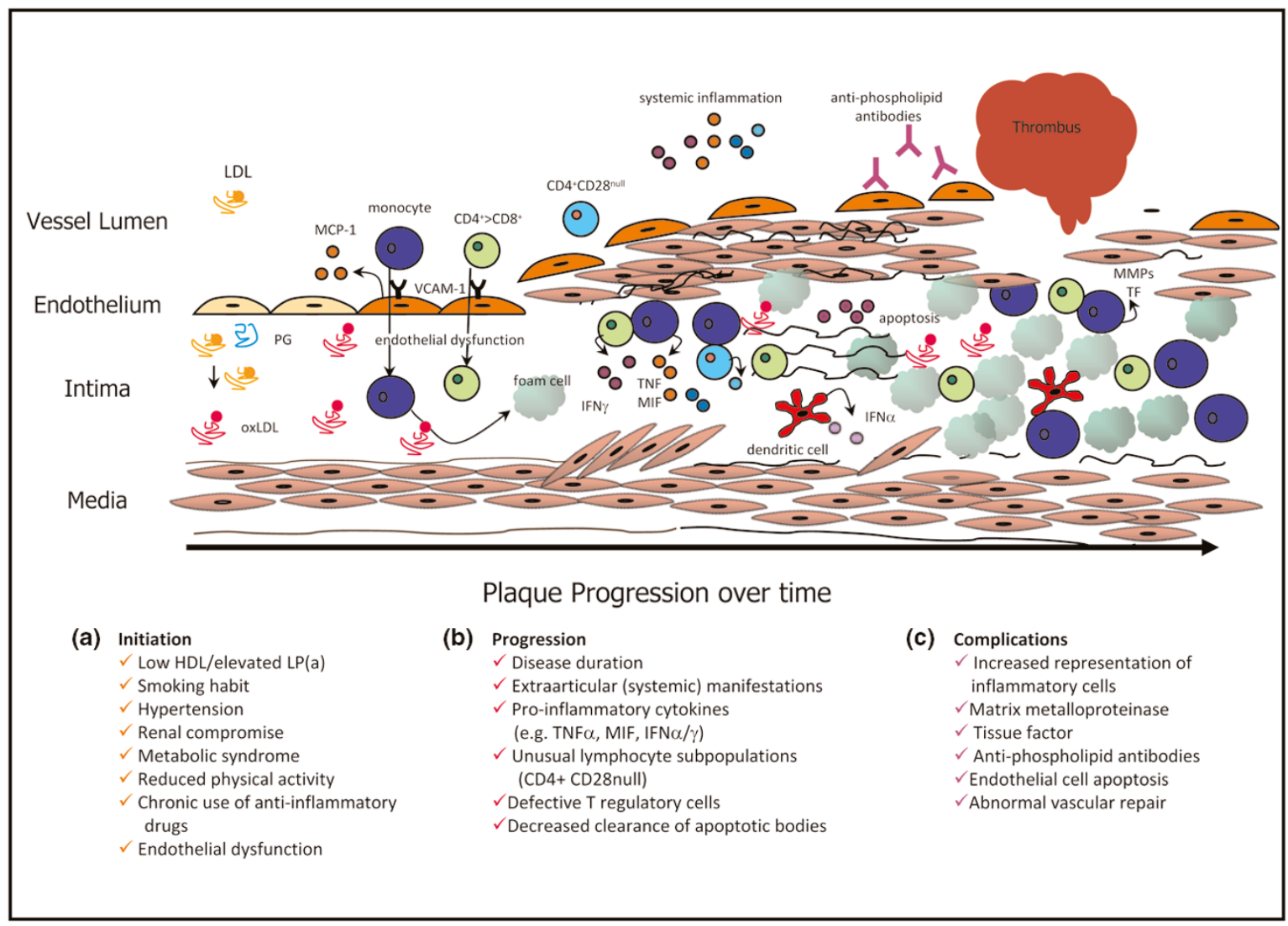

Formation and progression of atherosclerotic lesions. (a) Atherosclerosis disease initiation. Patients with rheumatoid arthritis and systemic lupus erythematosus present with clustering of traditional risk factors, notably low high-density lipoprotein (HDL) levels and pro-atherogenic lipid particles, leading to premature establishment of atherosclerotic lesions compared with age-matched and sex-matched control individuals. (b) Progression. Inflammatory disease activity and duration is emerging as a key determinant of the clinical association between cardiovascular disease (CVD) and inflammatory disease. Pro-inflammatory mediators and immune dysregulation features may enhance susceptibility to risk factors and establish chronic inflammation in vascular lesions. (c) Complications. Both inflammatory features and prothrombotic pathways may enhance the likelihood of acute events, increasing mortality. IFN, interferon; LDL, low-density lipoprotein; Lp(a), lipoprotein(a); MCP, monocyte chemoattractant protein; MIF, macrophage migration inhibitory factor; MMP, matrix metalloproteinase; oxLDL, oxidized low-density lipoprotein; PG, prostaglandin; VCAM, vascular cell adhesion molecule; TF, tissue factor; TNF, tumour necrosis factor.

of atherosclerosis, genetic deletion or blockade of chemokines (such as C-C chemokine ligands 2 and 5, and fractalkine and its cognate receptors) and adhesion molecules (such as vascular cell adhesion molecule-1) abrogates monocyte recruitment and atherosclerosis in mice [43]. Blood-borne monocytes recruited through the endothelium undergo differentiation into macrophages induced by macrophage colony-stimulating factor. During this process scavenger receptors are upregulated, mediating the uptake of oxLDL, causing the formation of foam cells, which are the hallmark of atherosclerotic lesions. Macrophages in atherosclerotic plaques exhibit features of activation and release a host of pro-inflammatory mediators including TNF- $\alpha$, which leads to the engagement of the pro-inflammatory cytokine cascade, resulting in IL- 1 and IL- 6 production. IL- 6 in turn stimulates production of large amounts of acute-phase reactants, including C-reactive protein, serum amyloid $A$ and fibrinogen in the liver.

Cytokine upregulation is a general feature of inflammatory diseases and could be a mechanism that links increased atheroma formation in patients with RA and SLE. Several cytokines with relevance to CVD could contribute to the pathogenesis of atherosclerosis in RA and SLE.

TNF- $\alpha$ plays a dominant role in RA. TNF- $\alpha$ induces a proinflammatory cascade, with upregulation of other mediators, namely IL-1, IL-6 and IL-8, prostaglandins and matrix metalloproteinases (MMPs). Upregulation of adhesion molecules by TNF- $\alpha$ on the vascular endothelium leads to cellular recruitment of neutrophils and monocytes. It also stimulates the proliferation of fibroblasts [49]. Introduction of the anti-TNF 
treatments has dramatically improved the outcome of severe RA [50]. Blockade of TNF- $\alpha$ in RA reduces circulating cytokine levels, leucocyte trafficking and platelet levels, all factors that may promote thrombotic and atherosclerotic complications [50]. In studies of hypercholesterolaemic apolipoprotein (apo) $\mathrm{E}^{-/}$mice, genetic deletion of TNF- $\alpha$ or treatment with recombinant soluble TNF receptor I led to a reduction in atherosclerotic lesions [51]. Experimental studies using apoE $\mathrm{E}^{-/-} \mathrm{TNF}^{-/}$mice also demonstrated a significantly smaller lesion size in the aortic sinus compared with that of apoE ${ }^{-/}$mice [51]. Although the failure of TNF blockers in heart failure has thus far discouraged further trials in other CVD, evidence to support the hypothesis that TNF blockers are protective against CVD has started to accumulate in RA cohorts. In a Swedish registry cohort [52], treatment with TNF inhibitors was associated with a lower incidence of first $\mathrm{Ml}$ in patients with RA. Anti-TNF treatment in RA patients increases HDL-cholesterol levels [53], insulin sensitivity [54] and reduces carotid IMT [55] and MI [56].

Recently, macrophage migration inhibitory factor (MIF) has emerged as a potential link between RA, SLE and atherosclerosis development (for review, see [57]). Originally, described as 'a soluble factor released from $\mathrm{T}$ cells in delayed hypersensitivity responses inhibiting migration of macrophages', MIF is considered a pleiotropic cytokine with roles in several inflammatory diseases. MIF induces the pro-inflammatory mediators TNF- $\alpha, \mathrm{IL}-1, \mathrm{IL}-6$ and MMPs. It can activate $\mathrm{T}$ cells, promote angiogenesis and induce proliferation of cells, while inhibiting p53 expression and apoptosis of the same cells $[57,58]$. MIF can be induced by oxLDL, which is an initiating factor in atherogenesis, and so expression of MIF early on may enhance pro-inflammatory responses and lesion progression [58]. MIF immunoneutralization or genetic deletion reduces disease activity in animal models of arthritis and lupus. In mice with advanced atherosclerosis, MIF blockade led to plaque regression and reduced monocyte and T-cell content in the plaques. Interestingly, glucocorticoids can induce the expression of MIF in multiple cell types [57], which is a function of potential relevance to the development of CVD in those patients receiving chronic treatment. Increased serum levels of MIF have been detected in SLE patients compared with healthy control individuals [57], and correlations were reported between MIF serum levels and SLE-related damage scores and glucocorticoid exposure.

The type I interferon cytokines (interferon [IFN]- $\alpha$ and IFN- $\beta$ ) play a causative role in SLE. Type I IFN- $\alpha$ is produced by dendritic cells in response to viral or bacterial infections, sensed through Toll-like receptor (TLR)-9. Auto-antigens such as self-DNA, exposed by apoptotic cells, may also trigger TLR-9 signalling, resulting in IFN- $\alpha$ production [59]. IFNs play many roles including inhibition of cell proliferation, interfering with viral infections, proliferation of memory $T$ cells and increased antigen presentation activity by dendritic cells
[60]. Type I IFNs were recently linked to impairment of vascular repair by circulating endothelial progenitor cells. SLE patients have decreased numbers of endothelial progenitor cells, with increased endothelial cell apoptosis, and decreased pro-angiogenic and repair capacity [59]. IFN- $\alpha$ has anti-proliferative effects on endothelial progenitor cells in vitro. SLE patients have elevated levels of IFN- $\alpha$, which correlates with disease severity [60] and impaired endothelial function [61]. Interestingly, IFN- $\alpha$ produced by plasmacytoid dendritic cells has been detected in human carotid plaques, where it could sensitize antigen-presenting cells to the TLR-4 ligand lipopolysaccharide, thereby promoting the production of pro-inflammatory molecules [62]. By contributing to endothelial dysfunction/damage and inducing pro-inflammatory responses within the atherosclerotic plaque, IFN- $\alpha$ could promote atherosclerosis in patients with inflammatory diseases.

\section{Lymphocytes and immune dysregulation}

$T$ cells infiltrate atherosclerotic lesions, even in early stages of disease. Such infiltrates are predominantly CD45RO-expressing memory $\mathrm{CD}^{+} \mathrm{T}$ cells, most of which bear the T-cell receptor $\alpha \beta$. They appear to be in close contact with major histocompatibility complex (MHC) class II expressing macrophages and dendritic cells. Both human and animal studies have thus far shown a predominantly T-helper (Th) 1 pattern in atherosclerosis, with immunopositivity for the classic Th1 cytokine IFN- $\gamma$ and Th1-stimulating cytokines IL12 and IL-18. In apoE ${ }^{-/-}$mice lacking IFN- $\gamma$ or its receptor, the development of atherosclerosis is inhibited [43].

During the past decade, an unusual subpopulation of $\mathrm{CD}^{+}$ T cells lacking the co-stimulatory receptor CD28 have been suggested to link atherosclerotic syndromes with RA. Such $\mathrm{CD}^{+} \mathrm{T}$ cells exhibit a spectrum of regulatory receptors that are usually only seen on natural killer cells. Such regulatory receptors include perforin, members of the killer immunoglobulin-like receptor family, and the receptor for the chemokine fractalkine. In RA, circulating CD4 ${ }^{+}$CD28null cells are increased and correlate with preclinical atherosclerotic disease and endothelial dysfunction. Such cells are also increased in the circulation and in plaques of patients with acute coronary syndrome (ACS) [63] and possess endothelial cell cytotoxic activity [64].

An additional mechanism that could also explain the increased incidence of CVD in patients with inflammatory diseases is the failure of regulatory feedback mechanisms, such as production of anti-inflammatory cytokines IL-10 and transforming growth factor (TGF)- $\beta$ by regulatory $T$ cells. T-cell-specific genetic deficiency in the TGF- $\beta$ receptor leads to plaque destabilization, whereas regulatory $T$ cells have the ability to reduce atherosclerotic burden in hyperlipidaemic mice [43]. In $\mathrm{RA} C D 4^{+} \mathrm{CD} 25^{+}$regulatory $\mathrm{T}$ cells have a defect in their suppressive functions, which was restored during treatment with TNF blockers [65]. 
The decreased clearance of apoptotic bodies has also been evoked to explain increased inflammation in lupus-like models of disease. The gld and Ipr mouse strains have inactivating mutations in Fas ligand and Fas, respectively, and they suffer from lupus-like disease. (Fas ligand and Fas are transmembrane proteins on the cell surface; binding of Fas ligand to its receptor Fas induces apoptosis.) Although these mice typically do not exhibit signs of atherosclerosis, they are susceptible to atherosclerotic lesion formation when they are fed an atherogenic diet [66]. ApoE $\mathrm{E}^{-/}$mice crossed with g/d mice developed lesions containing a twofold to threefold increase in macrophages and $\mathrm{CD}^{+}$lymphocytes as compared with apoE ${ }^{-/}$mice [67]. A similar increase in lymphocytes and macrophage accumulation within the lesions were observed after bone marrow transfer from lupusprone strains developed on a C57BL/6 background to LDL receptor-deficient mice $[68,69]$, even in the presence of lower levels of cholesterol and triglycerides. Furthermore, an increase in the expression of the MHC class II molecule I-Ab in mice with lupus-like disease compared with control animals was observed, and there were significantly higher antibody titres to oxLDL and cardiolipin [67-69].

\section{Thrombotic complications}

ACS such as MI occur when thrombosis ensues on an atherosclerotic plaque, suddenly limiting blood flow through the coronary artery. Acute thrombosis is often triggered by sudden plaque rupture or erosion [43], but heterogeneity of pathological substrates for thrombosis has been documented [70]. $\mathrm{Ml}$ is often caused by plaques that only moderately restrict the vessel lumen (by $<50 \%$ of the lumen diameter) [71].

\section{Plaque vulnerability}

The chance of plaque rupture is determined by the strength and thickness of the fibrous cap, surrounding the inflammatory and necrotic 'core' of the plaque. The cap, made up of smooth muscle cells (SMCs) either recruited from the media or derived from progenitors, forms a protective barrier encasing the core, preventing the prothrombotic material tissue factor and phospholipids - from contacting the arterial blood flow [43]. 'High-risk' atherosclerotic plaques are characterized by their composition rather than by their impact on the vessel lumen. A high-risk plaque is characterized by a large lipidic/necrotic core with increased number of activated monocytes and lymphocytes. The fibrous cap is also thinner due to SMC apoptosis and proteolytic degradation of the fibrous proteins. On the contrary, a 'stable' plaque is characterized by its thick fibrous cap, containing increased amounts of fibrous proteins and SMCs, and generally a smaller proinflammatory/prothrombotic core; such plaques are less prone to rupture.

There is evidence that plaques obtained from patients who have experienced an ACS have a higher content of macrophages and activated $\mathrm{T}$ lymphocytes at sites of coronary thrombosis [72]. Also, they are often found in clusters within the fibrous cap, in particular in the 'shoulder' area of the lesion, the border between normal vessel and atherosclerotic plaque, where plaque rupture is thought to occur most often. A retrospective autopsy study comparing 41 patients with RA with sex-, age- and autopsy date-matched control individuals did not identify significant differences between groups in severity of the coronary stenoses in cross-sectional area or the number of vessels affected. However, RA patients with clinical history of CVD were more likely to have coronary lesions with a 'high-risk' rather than a 'stable' plaque phenotype [73]. This finding is in agreement with a long 'silent' history of coronary artery disease, with increased incidence of $\mathrm{Ml}$ and sudden death $[5,6]$.

Plaque stability can be influenced by cytokines via a variety of mechanisms. First, cytokines can affect the amount of fibrous proteins produced by SMCs. IFN- $\gamma$ inhibits collagen production, whereas TGF- $\beta$ has the opposite effect. Second, cytokines such as TNF- $\alpha$ and IL-1 can induce expression of MMPs in SMCs and macrophages, which degrade the fibrous cap. MIF can induce MMP expression and may also contribute to plaque instability by increasing monocyte recruitment and retention in the plaque. Third, apoptosis of SMCs can be induced by IFN- $\gamma$ and TNF- $\alpha$. Finally, cytokines, in particular TNF- $\alpha$, can induce expression of tissue factor, which is the major initiator of the thrombotic cascade and whose increased expression is a feature of plaques in patients with ACS. Therefore, pro-inflammatory cytokines can have both a localized effect on the plaque architecture and determine occurrence of thrombotic events, and a more systemic effect, in which they affect cholesterol levels, insulin resistance and endothelial function.

\section{Genetic associations}

Recently, single nucleotide polymorphisms (SNPs) with an impact on immune responses have emerged as shared genetic risk factors in RA and $\mathrm{Ml}$. The expression of $\mathrm{MHC}$ class II is regulated by the transactivator MHC2TA. A SNP, namely the A168G polymorphism in the type III promoter of MHC2TA, was recently associated with RA, multiple sclerosis and Ml. This polymorphism was associated with lower expression of MHC2TA after stimulation of peripheral blood cells with IFN- $\gamma$, leading the authors to speculate that less efficient antigen presentation in response to inflammatory stimuli to regulatory $T$ cells may promote disease [74]. Interestingly, statins have been shown to downregulate MHC2TA expression by inhibition of the inducible IV promoter of MHC2TA [48]. However, no evidence of association of this MHC2TA variant with RA could subsequently be detected in independent cohorts $[75,76]$, and studies in larger sample sizes are awaited to clarify the role of this SNP in the aetiology of RA [75].

Interestingly, polymorphisms in the region of the TNFAIP3 gene were recently linked to RA and SLE $[77,78]$. TNFAIP3 encodes the de-ubiquitinating enzyme $\mathrm{A} 20$, an endogenous 
inhibitor of the nuclear factor- $\kappa \mathrm{B}(\mathrm{NF}-\kappa \mathrm{B})$ pathway. NF- $\mathrm{BB}$ is a transcription factor that is activated by TNF or IL-1/TLR signalling pathways, which induces transcription of proinflammatory genes. In atherosclerosis, NF- $\kappa B$ is activated at sites of the arterial wall that are prone to lesion development. In animal studies, ApoE $\mathrm{E}^{-/} \mathrm{A} 20^{\%}$ mice had increased atherosclerosis, whereas mice with A20 over-expression had decreased atherosclerosis [79]. SNPs in the TNFAIP3 gene region may cause reduced expression or reduced activity of A20 [77], therefore contributing to an uncontrolled inflammatory response and autoimmunity and potentially accelerated atherosclerosis in these patients.

\section{Antiphospholipid antibodies}

Antiphospholipid antibodies are the hallmark of the antiphospholipid syndrome, which is characterized by recurrent thrombosis and is associated with SLE. Between 30\% and $50 \%$ of patients with SLE have antiphospholipid antibodies, and approximately one-third develop antiphospholipid syndrome [23]. Many of these antibodies, such as anticardiolipin $(\mathrm{aCL})$, recognize phospholipid-binding plasma proteins such as $\beta_{2}$-glycoprotein I (GPI), which is anticoagulant. Nevertheless, there is some new evidence to suggest that they may also play a role in the development of atherosclerotic disease. Antibodies to $\beta_{2}$-GPI may lead to endothelial activation and/or damage, as well as enhance oxLDL uptake by macrophages, contributing to recruitment of immune cells to the vascular wall. Furthermore, immunization with $\beta_{2}$-GPI leads to vascular lesions in LDL receptor ${ }^{-/}$mice, suggesting that immune recognition might also play a role [80].

However, in SLE cohorts no correlation was found between aCL antibodies and indices of atherosclerosis extent and severity such as carotid IMT [81,82]. However, association was found with thrombotic complications such as MI. This paradox can potentially be explained by the ability of aCL to cause thrombosis even in the absence of underlying advanced atherosclerotic plaque [81]. Some patients with $\mathrm{RA}$ may have elevated levels of aCL [83]. In contrast with SLE patients, however, RA patients exhibited an increased carotid IMT compared with RA patients without elevated auto-antibodies [13]. However, in one study, only 17 out of 83 patients were found to have increased antibodies to aCL, and larger cohorts are needed to address this observation.

\section{Conclusions}

An increased prevalence of pro-atherogenic risk factors in patients with RA and SLE compared with age-matched control individuals may very well contribute to the initiating stages of disease. However, the dysregulated inflammation that characterizes inflammatory diseases may increase susceptibility to traditional risk factors and the likelihood that a chronic inflammatory response will ensue at the arterial sites. Potentially, shared pathogenic pathways are also at play. The dissection of the molecular mechanisms underlying atherosclerosis and classic inflammatory diseases will no doubt help us to understand how inflammation causes CVD in both the general population and in the subgroups of patients with inflammatory diseases.

\section{Competing interests}

The authors declare that they have no competing interests.

\section{Acknowledgements}

The Kennedy Institute of Rheumatology is funded by the Arthritis Research Campaign (ARC). Cristina Ruisanchez is supported by a research grant from the Marques de Valdecilla Foundation (Spain).

\section{References}

1. Ross R: Atherosclerosis-an inflammatory disease. $N$ Engl J Med 1999, 340:115-126.

2. Naranjo A, Sokka T, Descalzo MA, Calvo-Alen J, Horslev-Petersen K, Luukkainen RK, Combe B, Burmester GR, Devlin J, Ferraccioli $\mathrm{G}$, et al: Cardiovascular disease in patients with rheumatoid arthritis: results from the QUEST-RA study. Arthritis Res Ther 2008, 10:R30.

3. Wolfe F, Mitchell DM, Sibley JT, Fries JF, Bloch DA, Williams CA, Spitz PW, Haga M, Kleinheksel SM, Cathey MA: The mortality of rheumatoid arthritis. Arthritis Rheum 1994, 37:481-494.

4. Solomon DH, Karlson EW, Rimm EB, Cannuscio CC, Mandl LA, Manson JE, Stampfer MJ, Curhan GC: Cardiovascular morbidity and mortality in women diagnosed with rheumatoid arthritis. Circulation 2003, 107:1303-1307.

5. Maradit-Kremers H, Crowson CS, Nicola PJ, Ballman KV, Roger VL, Jacobsen SJ, Gabriel SE: Increased unrecognized coronary heart disease and sudden deaths in rheumatoid arthritis: a population-based cohort study. Arthritis Rheum 2005, 52:402411.

6. Maradit-Kremers H, Nicola PJ, Crowson CS, Ballman KV, Gabriel SE: Cardiovascular death in rheumatoid arthritis: a population-based study. Arthritis Rheum 2005, 52:722-732.

7. Park YB, Ahn CW, Choi HK, Lee SH, In BH, Lee HC, Nam CM, Lee SK: Atherosclerosis in rheumatoid arthritis: morphologic evidence obtained by carotid ultrasound. Arthritis Rheum 2002, 46:1714-1719.

8. Kumeda $Y$, Inaba M, Goto H, Nagata M, Henmi Y, Furumitsu $Y$, Ishimura $E$, Inui $K$, Yutani $Y$, Miki T, Shoji T, Nishizawa $Y$ : Increased thickness of the arterial intima-media detected by ultrasonography in patients with rheumatoid arthritis. Arthritis Rheum 2002, 46:1489-1497.

9. Warrington KJ, Kent PD, Frye RL, Lymp JF, Kopecky SL, Goronzy $\mathrm{JJ}$, Weyand CM: Rheumatoid arthritis is an independent risk factor for multi-vessel coronary artery disease: a case control study. Arthritis Res Ther 2005, 7:R984-R991.

10. Urowitz MB, Bookman AA, Koehler BE, Gordon DA, Smythe HA, Ogryzlo MA: The bimodal mortality pattern of systemic lupus erythematosus. Am J Med 1976, 60:221-225.

11. Manzi S, Meilahn EN, Rairie JE, Conte CG, Medsger TA, Jr., Jansen-McWilliams L, D'Agostino RB, Kuller LH: Age-specific incidence rates of myocardial infarction and angina in women with systemic lupus erythematosus: comparison with the Framingham Study. Am J Epidemiol 1997, 145:408-415.

12. Esdaile JM, Abrahamowicz M, Grodzicky T, Li Y, Panaritis C, du Berger R, Cote R, Grover SA, Fortin PR, Clarke AE, Senecal JL: Traditional Framingham risk factors fail to fully account for accelerated atherosclerosis in systemic lupus erythematosus. Arthritis Rheum 2001, 44:2331-2337.

13. Sherer Y, Gerli R, Gilburd B, Bartoloni Bocci E, Vaudo G, Mannarino $E$, Shoenfeld $Y$ : Thickened carotid artery intima-media in rheumatoid arthritis is associated with elevated anticardiolipin antibodies. Lupus 2007, 16:259-264.

14. Roman MJ, Shanker BA, Davis A, Lockshin MD, Sammaritano L, Simantov R, Crow MK, Schwartz JE, Paget SA, Devereux RB, Salmon JE: Prevalence and correlates of accelerated atherosclerosis in systemic lupus erythematosus. $N$ Engl $J$ Med 2003, 349:2399-2406.

15. Espinola-Zavaleta N, Alexanderson-Rosas E, Granados N, Elena Soto M, Amigo MC: Myocardial perfusion defects in patients with autoimmune diseases: a prospective study. Analysis of two diagnostic tests. Lupus 2006, 15:38-43. 
16. Bruce IN, Burns RJ, Gladman DD, Urowitz MB: Single photon emission computed tomography dual isotope myocardial perfusion imaging in women with systemic lupus erythematosus. I. Prevalence and distribution of abnormalities. J Rheumatol 2000, 27:2372-2377.

17. Asanuma $Y$, Oeser A, Shintani AK, Turner E, Olsen N, Fazio $S$, Linton MF, Raggi P, Stein CM: Premature coronary-artery atherosclerosis in systemic lupus erythematosus. $N$ Engl $\mathrm{J}$ Med 2003, 349:2407-2415.

18. del Rincon ID, Williams K, Stern MP, Freeman GL, Escalante A: High incidence of cardiovascular events in a rheumatoid arthritis cohort not explained by traditional cardiac risk factors. Arthritis Rheum 2001, 44:2737-2745.

19. Watson DJ, Rhodes T, Guess HA: All-cause mortality and vascular events among patients with rheumatoid arthritis, osteoarthritis, or no arthritis in the UK General Practice Research Database. J Rheumato/ 2003, 30:1196-1202.

20. Gerli R, Sherer Y, Vaudo G, Schillaci G, Gilburd B, Giordano A, Bocci EB, Allegrucci R, Marchesi S, Mannarino E, Shoenfeld Y: Early atherosclerosis in rheumatoid arthritis: effects of smoking on thickness of the carotid artery intima media. Ann N Y Acad Sci 2005, 1051:281-290.

21. Petri M, Perez-Gutthann S, Spence D, Hochberg MC: Risk factors for coronary artery disease in patients with systemic lupus erythematosus. Am J Med 1992, 93:513-519.

22. Dessein PH, Norton GR, Woodiwiss AJ, Joffe BI, Wolfe F: Influence of nonclassical cardiovascular risk factors on the accuracy of predicting subclinical atherosclerosis in rheumatoid arthritis. J Rheumatol 2007, 34:943-951.

23. Frostegard $\mathrm{J}$ : Atherosclerosis in patients with autoimmune disorders. Arterioscler Thromb Vasc Biol 2005, 25:1776-1785.

24. van Halm VP, Nielen MM, Nurmohamed MT, van Schaardenburg D, Reesink HW, Voskuyl AE, Twisk JW, van de Stadt RJ, de Koning $\mathrm{MH}$, Habibuw MR, van der Horst-Bruinsma IE, Dijkmans BA: Lipids and inflammation: serial measurements of the lipid profile of blood donors who later developed rheumatoid arthritis. Ann Rheum Dis 2007, 66:184-188.

25. Hurt-Camejo E, Paredes S, Masana L, Camejo G, Sartipy P, Rosengren B, Pedreno J, Vallve JC, Benito P, Wiklund O: Elevated levels of small, low-density lipoprotein with high affinity for arterial matrix components in patients with rheumatoid arthritis: possible contribution of phospholipase A2 to this atherogenic profile. Arthritis Rheum 2001, 44:2761-2767.

26. Svenungsson $E$, Jensen-Urstad $K$, Heimburger $M$, Silveira $A$, Hamsten A, de Faire U, Witztum JL, Frostegard J: Risk factors for cardiovascular disease in systemic lupus erythematosus. Circulation 2001, 104:1887-1893.

27. Delgado Alves J, Ames PR, Donohue S, Stanyer L, NouroozZadeh J, Ravirajan C, Isenberg DA: Antibodies to high-density lipoprotein and beta2-glycoprotein I are inversely correlated with paraoxonase activity in systemic lupus erythematosus and primary antiphospholipid syndrome. Arthritis Rheum 2002, 46:2686-2694.

28. Zonana-Nacach A, Santana-Sahagun E, Jimenez-Balderas FJ, Camargo-Coronel A: Prevalence and factors associated with metabolic syndrome in patients with rheumatoid arthritis and systemic lupus erythematosus. J Clin Rheumato/ 2008, 14:7477.

29. Boyer JF, Cantagrel A, Constantin A: Impact of traditional therapies and biologics on cardiovascular diseases in rheumatoid arthritis. Curr Vasc Pharmacol 2008, 6:218-227.

30. Boers M, Nurmohamed MT, Doelman CJ, Lard LR, Verhoeven AC, Voskuyl AE, Huizinga TW, van de Stadt RJ, Dijkmans BA, van der Linden S: Influence of glucocorticoids and disease activity on total and high density lipoprotein cholesterol in patients with rheumatoid arthritis. Ann Rheum Dis 2003, 62:842-845.

31. del Rincon I, O'Leary DH, Haas RW, Escalante A: Effect of glucocorticoids on the arteries in rheumatoid arthritis. Arthritis Rheum 2004, 50:3813-3822.

32. Petri M, Roubenoff R, Dallal GE, Nadeau MR, Selhub J, Rosenberg $\mathrm{H}$ : Plasma homocysteine as a risk factor for atherothrombotic events in systemic lupus erythematosus. Lancet 1996, 348:1120-1124.

33. Choi HK, Hernan MA, Seeger JD, Robins JM, Wolfe F: Methotrexate and mortality in patients with rheumatoid arthritis: a prospective study. Lancet 2002, 359:1173-1177.

34. Whittle SL, Hughes RA: Folate supplementation and methotrexate treatment in rheumatoid arthritis: a review. Rheumatology (Oxford) 2004, 43:267-271.

35. Albert CM, Cook NR, Gaziano JM, Zaharris E, MacFadyen J, Danielson E, Buring JE, Manson JE: Effect of folic acid and B vitamins on risk of cardiovascular events and total mortality among women at high risk for cardiovascular disease: a randomized trial. JAMA 2008, 299:2027-2036.

36. Kearney PM, Baigent C, Godwin J, Halls H, Emberson JR, Patrono C: Do selective cyclo-oxygenase-2 inhibitors and traditional non-steroidal anti-inflammatory drugs increase the risk of atherothrombosis? Meta-analysis of randomised trials. BMJ 2006, 332:1302-1308.

37. Jacobsson LT, Turesson C, Hanson RL, Pillemer S, Sievers ML, Pettitt DJ, Bennett PH, Knowler WC: Joint swelling as a predictor of death from cardiovascular disease in a population study of Pima Indians. Arthritis Rheum 2001, 44:1170-1176.

38. Turesson C, McClelland RL, Christianson TJ, Matteson EL: Severe extra-articular disease manifestations are associated with an increased risk of first ever cardiovascular events in patients with rheumatoid arthritis. Ann Rheum Dis 2007, 66: 70-75.

39. Gonzalez-Juanatey C, Llorca J, Testa A, Revuelta J, Garcia-Porrua C, Gonzalez-Gay MA: Increased prevalence of severe subclinical atherosclerotic findings in long-term treated rheumatoid arthritis patients without clinically evident atherosclerotic disease. Medicine (Baltimore) 2003, 82:407-413.

40. Del Rincon I, O'Leary DH, Freeman GL, Escalante A: Acceleration of atherosclerosis during the course of rheumatoid arthritis. Atherosclerosis 2007, 195:354-360.

41. Chung CP, Oeser A, Avalos I, Gebretsadik T, Shintani A, Raggi P, Sokka T, Pincus T, Stein CM: Utility of the Framingham risk score to predict the presence of coronary atherosclerosis in patients with rheumatoid arthritis. Arthritis Res Ther 2006, 8: R186.

42. Goodson NJ, Wiles NJ, Lunt M, Barrett EM, Silman AJ, Symmons DP: Mortality in early inflammatory polyarthritis: cardiovascular mortality is increased in seropositive patients. Arthritis Rheum 2002, 46:2010-2019.

43. Hansson GK: Inflammation, atherosclerosis, and coronary artery disease. N Engl J Med 2005, 352:1685-1695.

44. Pober JS: Endothelial activation: intracellular signaling pathways. Arthritis Res 2002, 4(suppl 3):S109-S116.

45. Bacon PA, Stevens RJ, Carruthers DM, Young SP, Kitas GD: Accelerated atherogenesis in autoimmune rheumatic diseases. Autoimmun Rev 2002, 1:338-347.

46. Quyyumi AA: Inflamed joints and stiff arteries: is rheumatoid arthritis a cardiovascular risk factor? Circulation 2006, 114: 1137-1139.

47. Ehrenstein MR, Jury EC, Mauri C: Statins for atherosclerosisas good as it gets? N Engl J Med 2005, 352:73-75.

48. Kwak B, Mulhaupt F, Myit S, Mach F: Statins as a newly recognized type of immunomodulator. Nat Med 2000, 6:1399-1402.

49. Maini RN, Elliott MJ, Brennan FM, Feldmann M: Beneficial effects of tumour necrosis factor-alpha (TNF-alpha) blockade in rheumatoid arthritis (RA). Clin Exp Immunol 1995, 101:207212.

50. Feldmann M, Maini RN: Lasker Clinical Medical Research Award. TNF defined as a therapeutic target for rheumatoid arthritis and other autoimmune diseases. Nat Med 2003 9:1245-1250.

51. Branen L, Hovgaard L, Nitulescu M, Bengtsson E, Nilsson J, Jovinge S: Inhibition of tumor necrosis factor-alpha reduces atherosclerosis in apolipoprotein $\mathrm{E}$ knockout mice. Arterioscler Thromb Vasc Biol 2004, 24:2137-2142.

52. Jacobsson LT, Turesson C, Gulfe A, Kapetanovic MC, Petersson IF, Saxne T, Geborek P: Treatment with tumor necrosis factor blockers is associated with a lower incidence of first cardiovascular events in patients with rheumatoid arthritis. $J$ Rheumato/ 2005, 32:1213-1218.

53. Allanore Y, Kahan A, Sellam J, Ekindjian OG, Borderie D: Effects of repeated infliximab therapy on serum lipid profile in patients with refractory rheumatoid arthritis. Clin Chim Acta 2006, 365:143-148

54. Kiortsis DN, Mavridis AK, Vasakos S, Nikas SN, Drosos AA: Effects of infliximab treatment on insulin resistance in patients with rheumatoid arthritis and ankylosing spondylitis. Ann Rheum Dis 2005, 64:765-766. 
55. Del Porto F, Lagana B, Lai S, Nofroni I, Tinti F, Vitale M, Podesta $E$, Mitterhofer AP, D'Amelio R: Response to anti-tumour necrosis factor alpha blockade is associated with reduction of carotid intima-media thickness in patients with active rheumatoid arthritis. Rheumatology (Oxford) 2007, 46:11111115.

56. Dixon WG, Watson KD, Lunt M, Hyrich KL, Silman AJ, Symmons DP: Reduction in the incidence of myocardial infarction in patients with rheumatoid arthritis who respond to anti-tumor necrosis factor alpha therapy: results from the British Society for Rheumatology Biologics Register. Arthritis Rheum 2007, 56:2905-2912.

57. Morand EF, Leech M, Bernhagen J: MIF: a new cytokine link between rheumatoid arthritis and atherosclerosis. Nat Rev Drug Discov 2006, 5:399-410.

58. Zernecke A, Bernhagen J, Weber C: Macrophage migration inhibitory factor in cardiovascular disease. Circulation 2008, 117:1594-1602.

59. Denny MF, Thacker S, Mehta H, Somers EC, Dodick T, Barrat FJ, McCune WJ, Kaplan MJ: Interferon-alpha promotes abnormal vasculogenesis in lupus: a potential pathway for premature atherosclerosis. Blood 2007, 110:2907-2915.

60. Ronnblom L, Alm GV: Systemic lupus erythematosus and the type I interferon system. Arthritis Res Ther 2003, 5:68-75.

61. Lee PY, Li Y, Richards HB, Chan FS, Zhuang H, Narain S, Butfiloski EJ, Sobel ES, Reeves WH, Segal MS: Type I interferon as a novel risk factor for endothelial progenitor cell depletion and endothelial dysfunction in systemic lupus erythematosus. Arthritis Rheum 2007, 56:3759-3769.

62. Niessner A, Shin MS, Pryshchep O, Goronzy JJ, Chaikof EL, Weyand CM: Synergistic proinflammatory effects of the antiviral cytokine interferon-alpha and Toll-like receptor 4 ligands in the atherosclerotic plaque. Circulation 2007, 116:20432052.

63. Liuzzo G, Biasucci LM, Trotta G, Brugaletta S, Pinnelli M, Digianuario G, Rizzello V, Rebuzzi AG, Rumi C, Maseri A, Crea F: Unusual $C D 4+C D 28$ null $T$ lymphocytes and recurrence of acute coronary events. J Am Coll Cardiol 2007, 50:1450-1458.

64. Nakajima T, Schulte S, Warrington KJ, Kopecky SL, Frye RL, Goronzy JJ, Weyand CM: T-cell-mediated lysis of endothelial cells in acute coronary syndromes. Circulation 2002, 105:570575.

65. Nadkarni S, Mauri C, Ehrenstein MR: Anti-TNF-alpha therapy induces a distinct regulatory $\mathrm{T}$ cell population in patients with rheumatoid arthritis via TGF-beta. J Exp Med 2007, 204:33-39.

66. Qiao JH, Castellani LW, Fishbein MC, Lusis AJ: Immunecomplex-mediated vasculitis increases coronary artery lipid accumulation in autoimmune-prone MRL mice. Arterioscler Thromb 1993, 13:932-943

67. Aprahamian T, Rifkin I, Bonegio R, Hugel B, Freyssinet JM, Sato K, Castellot JJ Jr, Walsh K: Impaired clearance of apoptotic cells promotes synergy between atherogenesis and autoimmune disease. J Exp Med 2004, 199:1121-1131.

68. Stanic AK, Stein CM, Morgan AC, Fazio S, Linton MF, Wakeland EK, Olsen NJ, Major AS: Immune dysregulation accelerates atherosclerosis and modulates plaque composition in systemic lupus erythematosus. Proc Natl Acad Sci USA 2006, 103:7018-7023.

69. Gautier EL, Huby T, Ouzilleau B, Doucet C, Saint-Charles F, Gremy G, Chapman MJ, Lesnik P: Enhanced immune system activation and arterial inflammation accelerates atherosclerosis in lupus-prone mice. Arterioscler Thromb Vasc Biol 2007, 27:1625-1631.

70. Virmani R, Burke AP, Farb A, Kolodgie FD: Pathology of the vulnerable plaque. J Am Coll Cardiol 2006, 47:C13-18.

71. Little WC, Constantinescu M, Applegate RJ, Kutcher MA, Burrows MT, Kahl FR, Santamore WP: Can coronary angiography predict the site of a subsequent myocardial infarction in patients with mild-to-moderate coronary artery disease? Circulation 1988, 78:1157-1166.

72. van der Wal AC, Becker AE, van der Loos CM, Das PK: Site of intimal rupture or erosion of thrombosed coronary atherosclerotic plaques is characterized by an inflammatory process irrespective of the dominant plaque morphology. Circulation 1994, 89:36-44.

73. Aubry MC, Maradit-Kremers H, Reinalda MS, Crowson CS, Edwards WD, Gabriel SE: Differences in atherosclerotic coro- nary heart disease between subjects with and without rheumatoid arthritis. J Rheumato/ 2007, 34:937-942.

74. Swanberg $M$, Lidman $O$, Padyukov $L$, Eriksson $P$, Akesson $E$ Jagodic M, Lobell A, Khademi M, Börjesson O, Lindgren CM Lundman $\mathrm{P}$, Brookes AJ, Kere J, Luthman $\mathrm{H}$, Alfredsson L, Hillert J, Klareskog L, Hamsten A, Piehl F, Olsson T: MHC2TA is associated with differential MHC molecule expression and susceptibility to rheumatoid arthritis, multiple sclerosis and myocardial infarction. Nat Genet 2005, 37:486-494.

75. Eyre S, Bowes J, Spreckley K, Potter C, Ring S, Strachan D, Worthington J, Barton A: Investigation of the MHC2TA gene, associated with rheumatoid arthritis in a Swedish population, in a UK rheumatoid arthritis cohort. Arthritis Rheum 2006, 54: 3417-3422.

76. Bronson PG, Criswell LA, Barcellos LF: The MHC2TA -168A/G polymorphism and risk for rheumatoid arthritis: a meta-analysis of 6861 patients and 9270 controls reveals no evidence for association. Ann Rheum Dis 2008, 67:933-936.

77. Musone SL, Taylor KE, Lu TT, Nititham J, Ferreira RC, Ortmann W, Shifrin N, Petri MA, llyas Kamboh M, Manzi S, Seldin MF, Gregersen PK, Behrens TW, Ma A, Kwok PY, Criswell LA: Multiple polymorphisms in the TNFAIP3 region are independently associated with systemic lupus erythematosus. Nat Genet 2008 [Epub ahead of print].

78. Plenge RM, Cotsapas C, Davies L, Price AL, de Bakker PI, Maller J, Pe'er I, Burtt NP, Blumenstiel B, DeFelice M, Parkin M, Barry R, Winslow W, Healy C, Graham RR, Neale BM, Izmailova E, Roubenoff R, Parker AN, Glass R, Karlson EW, Maher N, Hafler DA, Lee DM, Seldin MF, Remmers EF, Lee AT, Padyukov L, Alfredsson L, Coblyn J, et al.: Two independent alleles at 6q23 associated with risk of rheumatoid arthritis. Nat Genet 2007 , 39:1477-1482

79. Wolfrum S, Teupser D, Tan M, Chen KY, Breslow JL: The protective effect of A20 on atherosclerosis in apolipoprotein E-deficient mice is associated with reduced expression of NF-kappaB target genes. Proc Natl Acad Sci USA 2007, 104: 18601-18606

80. George J, Afek A, Gilburd B, Blank M, Levy Y, Aron-Maor A, Levkovitz H, Shaish A, Goldberg I, Kopolovic J, Harats D, Shoenfeld Y: Induction of early atherosclerosis in LDL-receptor-deficient mice immunized with beta2-glycoprotein I. Circulation 1998, 98:1108-1115.

81. Petri M: The lupus anticoagulant is a risk factor for myocardial infarction (but not atherosclerosis): Hopkins Lupus Cohort Thromb Res 2004, 114:593-595.

82. Farzaneh-Far A, Roman MJ, Lockshin MD, Devereux RB, Paget SA, Crow MK, Davis A, Sammaritano L, Levine DM, Salmon JE: Relationship of antiphospholipid antibodies to cardiovascular manifestations of systemic lupus erythematosus. Arthritis Rheum 2006, 54:3918-3925.

83. Jacobs R, Butler MG, Scott DL: Antibodies to cardiolipin and intermediate filaments: a study of autoimmunity in rheumatoid arthritis. Clin Rheumatol 1990, 9:509-516.

84. Wolfe F, Freundlich B, Straus WL: Increase in cardiovascular and cerebrovascular disease prevalence in rheumatoid arthritis. J Rheumato/ 2003, 30:36-40.

85. Assous N, Touze E, Meune C, Kahan A, Allanore Y: Cardiovascular disease in rheumatoid arthritis: single-center hospitalbased cohort study in France. Joint Bone Spine 2007, 74: 66-72.

86. Ward MM: Premature morbidity from cardiovascular and cerebrovascular diseases in women with systemic lupus erythematosus. Arthritis Rheum 1999, 42:338-346.

87. Bessant R, Hingorani A, Patel L, MacGregor A, Isenberg DA Rahman A: Risk of coronary heart disease and stroke in a large British cohort of patients with systemic lupus erythematosus. Rheumatology (Oxford) 2004, 43:924-929.

88. Fischer LM, Schlienger RG, Matter C, Jick H, Meier CR: Effect of rheumatoid arthritis or systemic lupus erythematosus on the risk of first-time acute myocardial infarction. $A m$ J Cardiol 2004, 93:198-200. 